\title{
Takaful Protection for Mental Health Illness From the Perspective of Maqasid Shariah
}

\author{
Khairil Faizal Khairi ${ }^{1}$, Mohamad Subini Abdul Samat ${ }^{1}$, Nur Hidayah Laili ${ }^{1}$, Hisham Sabri ${ }^{1}$, Mohd Yazis Ali Basah ${ }^{1}$, \\ Asmaddy Haris ${ }^{1} \&$ Azrul Azlan Iskandar Mirza ${ }^{1}$ \\ ${ }^{1}$ Faculty of Economics and Muamalat, Universiti Sains Islam Malaysia, Malaysia \\ Correspondence: Khairil Faizal Khairi, Faculty of Economics and Muamalat, Universiti Sains Islam Malaysia, \\ Malaysia.
}

Received: May 12, 2020

doi:10.5430/ijfr.v11n3p168
Accepted: June 20, 2020

Online Published: June 29, 2020

URL: https://doi.org/10.5430/ijfr.v11n3p168

\begin{abstract}
Mental health illness becomes one of the major illnesses in Malaysia aside from heart disease. It was recently reported that $29.2 \%$ of Malaysians are suffering from mental health illness which increases threefold from the previous year. Majority of the Malaysians suffering from mental health illness comes from the lowest income group. This shows that the lowest income group has less opportunity to seek treatment due to the cost. Even though other countries have started to offer mental health insurance such as the United States of America, United Kingdom, Australia and recently Singapore, Malaysia is still way behind in offering coverage for mental health illness. Therefore, the objective of this paper is to study the mental health takaful from the perspective of Maqasid shariah. The results from this study show that mental health takaful is able to meet the requirement of Maqasid shariah and preserve the benefits of, and prevent harm to human wellbeing. Furthermore, this study will provide an insight to the takaful industry for developing new products that could help mental health disorder patients.
\end{abstract}

Keywords: takaful, mental health, Maqasid Shariah, Islamic wealth management

\section{Introduction}

Takaful industry has been developed for more than a decade in Malaysia. Takaful or Islamic insurance has already existed during the time of early second century of Islamic era when Muslim Arabs expanded their business within Asia (Alhabshi et al., 2009; Yassin \& Ramly, 2011). Takaful is a simple mutual risk sharing between two parties that provide protection when mishaps happen (Hussain et al., 2011). Takaful has produced many products that cover almost any possible risk in daily life. Majority of insurance products are available in takaful product. However, as time goes on, there are several risks that are inconsistent and classified as high risk for takaful coverage. One of the major risks identified as high is mental health illness. According to all Malaysian takaful medical health policies, mental health is not covered within the policy.

According to the Ministry of Health Malaysia, mental health disorder is expected to be the second highest form of health problem affecting Malaysians after heart disease by 2020 (Institute Public Health, 2015). Meanwhile, according to the report of ASEAN Mental Health System 2016, mental disorders were 8.6\% of the total Disability Adjusted Life Years for Malaysians. This shows that mental disorder is ranked fourth for the leading cause of disease in Malaysia. The rise of mental health illness in Malaysia should not be taken lightly as majority of the mental health illness patients come from lower- and middle-income groups (Lim Su Lin, 2018; Ratod et al., 2017). There is a barrier for low income group to access proper mental health treatment due to the cost. Therefore, the need of takaful coverage for mental health is deemed necessary as takaful is one of the instruments to alleviate poverty and deprivation (Patel, 2004; Omar Fisher, 1999).

Islam is basically a way of life for Muslims in which it addresses the whole aspect of individual and society within this world and the hereafter (Radzi et al., 2018). Therefore, daily affairs are governed by Islamic law or shariah law. The highest objective of the shariah law is briefly explained in Maqasid shariah (Nordin, 2016). Maqasid shariah defines the purpose of every aspect of Muslim's individual, societal, national and global life (Nordin, 2016). According to Aznan Hassan (2011), Maqasid shariah is classified into three categories which are dharuriyyat (necessity), hajiyyat (needs) and tahsiniyyat (complementary). Therefore, to understand the concept of Maqasid shariah, it is important to clarify the necessity of mental health takaful in protecting Muslim needs. 
In relation to this, the current study intends to explore the relationship between takaful, mental health illness and Maqasid shariah. The remainder of the paper is organized as follows: Section two reviews the concept of takaful and the need of mental health takaful. Section three discusses mental health in Malaysia. Section four discusses the concept of Maqasid shariah. Section five presents the methodology applied in this research paper and section six thoroughly discusses mental health takaful from the perspective of Maqasid shariah. Finally, the final section concludes the summary of this research paper.

\section{Concept of Takaful and the Need of Mental Health Takaful}

The word Takaful is derived from its Arabic root word 'kafala' which literally means 'to guarantee (Alhabshi et al, 2011). "Kafala" is defined by Alhabshi (2011), as the agreement by one party to indemnify another for any liability that has been pre-agreed upon. Besides that, AAOIFI (2015, p.678), defined takaful as "a system through which the participants donate a part or all of their contributions to pay claims for damaged suffered by some of the participants. This definitely enlightens the core concept of takaful which is tabarru' (Yassin \& Ramli, 2011). Tabarru' means donation, gift or contribution in which each takaful participant who needs protection must have the intention to donate the contributions to the other participants that face difficulty (Yassin \& Ramli, 2011). Besides, Alhabshi et al, (2012) summarized the fundamental principles of takaful as cooperative insurance which each participating member is willing to contribute some amount of money to the members who face the same risk or danger. Meanwhile in Takaful Act 1984-part one section two, defined takaful as;

"Takaful" means a scheme based on brotherhood, solidarity and mutual assistance which provides for mutual financial aid and assistance to the participants in case of need whereby the participants mutually agree to contribute for that purpose;

"takaful benefits" includes any benefit, pecuniary or not which is secured by a takaful certificate, and "pay" and other expressions, where used in relation to takaful benefits, shall be construed accordingly;

"takaful business" means business of takaful whose aims and operations do not involve any element which is not approved by the Syariah"

It is known that conventional insurance is totally different from Islamic insurance (takaful). Conventional insurance has three elements that contradict takaful. According to Lim, Jacky, Muhammad Fahmi Idris, and Yura Carissa (2010), conventional insurance is prohibited due to the elements of Riba (interest), Gharar (uncertainty) and Maisir (gambling). Malaysia has achieved significant milestones in the development of its takaful industry. With the enactment of the Takaful Act 1984, the first takaful company was established in 1985. Since then, Malaysia's takaful industry has been gaining momentum and increasingly recognised as a significant contributor to Malaysia's overall Islamic financial system (Bank Negara, 2014).

Takaful is one of the protection schemes under Islamic wealth management. The objective of the takaful is to provide protection and assurance against a specific risk that befalls an individual's life or possessions (Aris et al., 2012; Abdullah,2012; Ahmed,2013). Besides that, takaful also counters poverty and deprivation (Fisher, 1999; Patel, 2004; Erlbeck, 2010; Bakhtiari, 2013; Hasim, 2014; Sheila et al., 2015). However, majority of takaful operator in Malaysia focuses more on middle and high income group instead of lower income group (Sheila et al., 2015). This happens because the majority of lower income group choose to lapse their policy if there is an increase in their takaful plan (Toh, 2017).

According to the department of statistics Malaysia, majority of Malaysians come from middle and high income group. Therefore, it is relevant for takaful operators to focus on middle and high income group. Despite that, government and private insurers already develop an insurance and takaful scheme for lower income group especially for health insurance (The Star, 2018). This event leads to the increasing opportunity of lower income group subscribing to takaful plan. Moreover, takaful operators may initiate new products suitable for lower income group such as micro takaful (Erlbeck, 2010; Bakhtiari, 2013; Hasim, 2014, Sheila et al., 2015).

Majority of Malaysians subscribe to medical and health takaful as the cost of getting treatment is expensive especially in private hospitals and for critical illnesses. There are 36 critical illness included in medical and health takaful such as heart disease, cancer, stroke and others. However, mental health illness is not even in the critical illness list even though mental health illness is recorded as the second highest health problem after heart disease (Institute Public Health, 2015). Mental health problems among Malaysians are in dire situation as one in three adults suffer from mental health problems (Lim Su Lin, 2018). According to Lim Su Lin (2018), Malaysian mental health problems were dominated by lower income group from year 1995 to 2016. However, there is a continuous rise from 
high income earners for mental health illness. There is a significant relationship between income and mental health disorder (Sareen et al., 2011; Bell et al., 2019).

Even though Malaysia still does not provide any takaful and insurance for mental health illness, other countries have already taken a step forward by including mental health illness in medical and health insurance. As for USA, health insurance plans are required to cover mental health and substance use disorder according to the Affordable Care Act, 2010 (Mental Health America, 2013). Meanwhile, AIA Singapore recently launched AIA beyond critical care that provides coverage for mental health conditions. This policy currently covers five mental illnesses which are Major Depressive Disorders (MDD), Schizophrenia, Bipolar Disorder, Obsessive Compulsive Disorder (OCD), and Tourette syndrome (Joanna \& Dawn, 2019). Therefore, Malaysian takaful operators need to start developing a takaful plan that caters for mental health conditions as mental health illness is one of the major health problems in Malaysia.

\section{Mental Health in Malaysia}

Lately, the mental health disorder is commonly discussed among experts as well as in the media. The increasing workload and stress-induced jobs have increased the mental health cases among workers. The effect of mental health disorder could directly give bad impact to the patients' career and life. Thus, the need of insurance cover to protect the person involved is highly recommended. However, having a mental health problem could cost higher premium as the insurance company thinks the person is more likely to make a claim on the insurance (Bijal et al., 2019). Mental health disorder is classified as pre-existing medical condition. A pre-existing medical condition is any condition you have at the time one applies for insurance. However, not all people have a history of mental health disorder. Thus, the classification of mental health disorder as one of pre-existing medical conditions is invalid. Having a mental health problem could be challenging for getting an insurance. There are several challenges such as insurance companies deemed customers as "high risk", the process of applying is difficult, the premium charged will cost more than normal and it is difficult to get the cover that is supposed to be claimed (Bijal et al., 2019).

The World Health Organizations defined mental health as "a state of well-being in which the individual realizes his or her own abilities, can cope with the normal stresses of life, can work productively and fruitfully and is able to make a contribution to his or her community". In Malaysia, the Ministry of Health defined mental health as "the capacity of the individual, the group and environment to interact with one another to promote subjective well-being and optimal functioning, and the use of cognitive, affective and relational abilities towards the achievement of individual and collective goals consistent with justice". Since Malaysia is a multicultural country, the concepts of mental health disorders can and have been addressed from different perspectives, representing the influence of various races and religious beliefs.

In Malaysia also, mental health is ranked as the second highest illness after cancer (Institute for Public Health, 2015). Furthermore, in National Health Morbidity Survey (NHMS) 2015, shown that mental health problems among adults show an increasing trend from $10.7 \%$ in 1996 to $29.2 \%$ in 2015. Moreover, the survey reported that females, younger adults, bumiputras and adults from low income families seem to suffer from mental health problems more commonly.

Furthermore, the cost of treatment for mental health disorder is more expensive than physical illness (Haque, 2005). According to the Ministry of Health website 2018, the cost of getting a consultation and treatment for mental health disorder in public hospital is around RM 5 TO RM 30 while in private hospital the cost is around RM 80 to RM 400. Even though the public hospital provides a cheaper and almost free treatment, the number of specialists and experts for mental health is almost none unless it is in big hospitals. According to Lim Su Lin (2018), Sarawak does not have any clinical psychologist to cater for mental health disorder consultation. Specialists and experts for mental health disorder are only available in big hospitals such as Hospital Kuala Lumpur, Hospital Kajang, and so on. According to Lim Su Lin (2018), currently Malaysia face critical shortage of clinical psychologists and only few are based in government mental health services.

Mental Health Services in Malaysia have long been confined to psychiatry whose history in this country dated back as early as 1827 (Jamaiyah, 2000). However, aspects of prevention of mental disorders and promotion of mental health still lag behind. The public health burden of mental health problems and disorders are now at the dire stage because of the increase in today's medical expenses.

Currently, in Malaysia there is no insurance and takaful provider that provide a mental health disorder coverage. All takaful and insurance providers in Malaysia state that medical benefit coverage does not include psychotic, mental or nervous disorder. According to Lim Su Lin (2018), standard health insurance policies do not cover pre-existing conditions including mental illness. Pre-existing condition is any condition in which the patient has already received 
medical advice or treatment prior to enrolment in a new medical insurance plan (Hudson et al., 1995). Due to this, people are discouraged to seek treatment as they feel mental disorder is severe illness that should not be known to others (Lim Su Lin, 2018). Thus, there is a need for a more comprehensive outlook of mental health services especially the role of takaful in the country to address this issue.

\section{Concept of Maqasid Shariah}

The word Maqasid is derived from the plural of "Maqsad" and comes from "Qasada" (Khairil et al., 2017). Qasada or Al-Qasd has a variety of meanings from the language perspective and one of them is to intend (Sadatmoosavi et al., 2015). Meanwhile, shariah is coming from the word shara' $a$ which is defined as introduce, organize and assign (Khairil et al., 2017). Besides that, shariah is also defined as a path to water hole and may be briefly explained as the law of God as revealed to the Prophet (Khairil et al., 2017; Sadatmoosavi et al., 2015). Thus, the meaning of Maqasid shariah is objective of Islamic law (Nordin, 2016; Nadhirah Nordin et al., 2017 \& Qoyum, 2018).

The study of Maqasid shariah is important to fulfil the objective of Islamic law and to indirectly accomplish maslahah (benefit) and to uphold justice for human beings (Nadhirah Nordin et al., 2017). There are so many scholars who discussed the concept of Maqasid shariah such as Al-Ghazali, Abu Ishaq al-Shatibi, al-'Izz ibn 'Abd aI-Salam, Ibn Qayyim al-Jawiziyyah, Ibn Ashur and Ahmad Al-Raisuni. Among them, Al-Ghazali defined Maqasid shariah as:

"The objective of the sharia is to promote the welfare of human beings, which lies in safeguarding their faith, their life, their intellect, their posterity, and their wealth. Whatever ensures the safeguard of these five fundamentals serves public interest and is desirable"

(As cited in Qoyum, 2018).

Apart from that, Al-Ghazali, classified Maqasid shariah into three which are darurriyyah (necessity), hajiyyah (needs) and tahsiniyyah (complementary). Darurriyyah refers to the basic necessity that needs to be accomplished for the welfare of human being (Ahmed, 2013). There are five primary objectives under darurriyyah that cover the necessity of human being. These objectives are:
a. Protection of the religion (Ad-din)
b. Protection of life (An-Nafs)
c. Protection of intellect (Al-A'ql)
d. Protection of progeny (An-Nasl)
e. Protection of property (Al-Mal)

Meanwhile, Al-Shatibi (1999), deemed these five protections as darurriyah (necessity) to accomplish the welfare of human beings. There are two possible ways according to Al-Shatibi to achieve the five protections mentioned before:

a. Necessities required for bringing into and maintaining the very existence of the above-mentioned elements, namely: din, nafs, nasi, mal, and 'aql.

b. Necessities required for protecting these elements from their destruction. The worships ('ibadah) for example, aim at maintaining the very existence of faith.

The necessities to maintain and protect the five objectives of Maqasid shariah must be achieved in order to accomplish welfare for human beings. For example, the necessities for maintaining the protection of religion are prayer, hajj, zakat and fasting (Abdul Aziz, 2013). Therefore, any activities that lead to the protecting and maintaining the five objectives of Maqasid shariah are deemed as important for human beings. Thus, it is important for takaful operators to provide an alternative to protect and maintain Maqasid shariah for the sake of welfare.

\section{Methodology}

This research adopted a qualitative research approach to meet the research objective. According to Gephart (2004), qualitative research is commonly used in the field of management. Furthermore, qualitative research provides in depth understanding on particular issues (Hoepfl, 1997). Besides that, this study is deemed as qualitative according to the literature review that has been gathered through library research. This study basically used secondary data collected from various sources namely; journal, conference journal, classical books, library, authoritative documents, research reports, data statistics and any official report related to takaful protection for mental health. 


\section{Mental Health Takaful From the Perspective of Maqasid Shariah}

This section briefly discusses the relationship between mental health takaful and Maqasid shariah. The discussion focuses on the five basic elements that exist in the concept of maslahah (darurriyyah) namely protection of the religion, life, intellect, progeny and property (Azhari, 2010). Brief discussion for the five basic elements in maintaining and protecting Maqasid shariah is as follows:

\subsection{Protection of Religion}

Takaful is another option for Muslims to choose riba-free insurance for protection against any risk that befalls on an individual or a group. In this case, mental health takaful provides an early assistance for mental health patients to seek help from the specialists. According to Jasser Auda (2008), maintaining and protecting the physical and mental health is one of the important aspects in protection of religion. Good physical and mental health contribute to the good ibadah. Besides that, without mental health takaful, the deterioration of mental health will cause a Muslim to be unable to perform ibadah. According to Sekandari (2017), obsessive compulsive disorder could hinder a Muslim to perform prayers as the patients tend to be repetitive in certain behaviours. Good mental health has a significant relationship with good ability to perform and focus on ibadah (Sayeed et al., 2013). Therefore, initiating mental health takaful could directly and indirectly help a Muslim in maintaining and protecting the religion.

\subsection{Protection of Life}

Islam is a way of life and one of the many morals in Islam is helping others. Allah swt ordered mankind to work and help each other and inhibit unlawful things. Allah S.W.T said in Surah Al-Maidah verse 2:

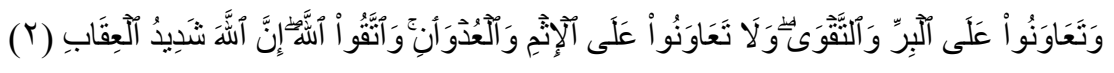

(Al-Maidah 5:2)

Translation: "And cooperate in righteousness and piety, but do not cooperate in sin and aggression. And fear Allah; indeed, Allah is severe in penalty."

One of the principals of takaful is helping other participants by contributing to pool fund for any risk happening to the participants. Therefore, mental health takaful could provide a good support for mental health patient recovering from the illness. The concept of takaful which is helping each other in risk or catastrophe indeed fulfils Maqasid shariah.

Besides that, mental health illness could lead to harm life such as suicide (Appleby et al., 1999 \& Sveen et al., 2008). A Muslim is supposed to maintain good physical and mental health before the appointed time of death arrives. Besides that, good health is one of the necessities for a human being which needs to be accomplished under Maqasid shariah. An early treatment for mental health illness is one of the ways of preservation and maintenance of good health. Thus, mental health takaful could prolong the life, increase quality of life for the patients of mental illness, and fulfil the protection of life.

\subsection{Protection of Intellect}

Major objective to initiate mental health takaful is to preserve and prolong the mental health of patients. One of the problems for mental health patient is in decision making process (Duncan et al., 2010 \& Schauer et al., 2007). The ability to make a decision with sound mind is a basic necessity for human being. Inability to make a sound decision will lead to destructive lifestyle. Patients with a mental health condition will face difficulty in thinking process. Early intervention by psychiatrists could help protect the intellect of patients. Once again, mental health takaful could help mental health patients receive early treatment for the preservation of patient's intellectuality and cognitive skill.

\subsection{Protection of Progeny}

From the perspective of mental health, a patient of mental health has limited social life. Due to the mental health condition, people are aware and distance themselves from the patients. There is still a taboo for people to talk about mental health and to admit having mental health illness. Good social life will increase the health of mental and reduce the possibility of depression and stress (Thoits, 2011). Besides that, mental health problem could affect anyone from children to adolescents (Ford, 2003 \& O'Neil et al., 2014). Mental health problem could even affect an offspring through parents (O'Neil et al., 2014). Early prevention of mental health problems could lead to quality life and better future for our children as well as our community (Min and Lee, 2013). The lack of early treatment and intervention leads to severe mental health problem. Thus, providing a coverage for mental health illness could be one of the acts of early intervention for mental health patients. Therefore, mental health takaful could enhance the chance of child and adolescent mental health patients to recover and function as healthy community members. Moreover, 
initiating a mental health takaful will increase protection of the next generation which leads to protection of progeny.

\subsection{Protection of Property}

Basically, a human being needs to survive by getting a job to acquire wealth. However, for mental health patients, getting a job or even maintaining a job is a big obstacle. Most employers believe that a mental health patient is a risk to their company. According to the Ministry of Health Malaysia, at some point Malaysia will have to face a mood disorder and anxiety disorder such as depression and bipolar disorder. A lot of companies are skeptical about the ability of mental health patients to fulfil their work responsibility. Majority of mental health patients are facing serious discrimination on landing a job. Moreover, severe mental health patients are unlikely to sign a contract for any property purchasing due to unstable mental condition. In Malaysia also, patients of mental health are not allowed to subscribe any takaful plan due to mental health illness. This is because mental health illness is considered as a pre-existing condition in takaful policies (Lim Su Lin, 20018). Therefore, Malaysia is really in need of any takaful plan that provides a coverage for mental health. From the perspective of Maqasid shariah, takaful operators need to initiate a mental health takaful to provide an opportunity for mental health patients to survive as well as to protect their wealth.

\section{Conclusion}

It is hoped that this study could enlighten government, takaful industry and Malaysians as a whole on the dire situation of mental health takaful. Moreover, the government and takaful companies could consider an appropriate assessment for initiating mental health takaful from this study. According to Nora'inan Bahari (2015), maslahah needs to fulfil the purpose of syara' and Maqasid syariah will not be fulfilled until it completes the purpose of maslahah and avoid mafsadah. Basically, mental health takaful could preserve and protect the objective of Maqasid shariah. Mental health takaful fulfils the purposes of maslahah which are the protection of religion, life, intellect, progeny and property. Initiating a mental health takaful will open a wide opportunity to takaful market as well as an option for takaful participants. Majority of Malaysian mental health patients come from lower and middle income group. The availability of mental health takaful could help many less fortunate citizens in receiving treatment for mental health. Lastly, it is hoped that through this study, there will be more research exploring the prospect of mental health takaful as in present, none of the research available on mental health takaful.

\section{Acknowledgements}

This paper is a part of a research project entitled: Formulating the Takaful Model under an Islamic Wealth Protection Scheme for Mental Health Disorders towards Societal Wellbeing in Malaysia - project reference code (FRGS/1/2017/SS01/USIM/02/11). This project is funded by the Ministry of Higher Education of Malaysia (MOHE).

\section{References}

AAOIFI. (2015). Financial accounting standards. Accounting and Auditing Organization for Islamic Financial Institutions. Manama, Bahrain.

Abdul Aziz, A. F., \& Mohamad, S. (2013). Fulfillment of Maqasid al-Shariah via Takaful (No. 47776). University Library of Munich, Germany.

Abdullah, S. (2012). Risk management via Takaful from a perspective of Maqasid of Shariah. Procedia-Social and Behavioral Sciences, 65, 535-541.

Affordable Care Act Toolkit: MHA. (2013). Retrieved February 27, 2019, from http://www.mentalhealthamerica.net/issues/affordable-care-act-toolkit-mha

Ahmed, Z. (2013). Achieving Maqasid al Shariah through Takaful. Retrieved December, 1, 2013.

Alhabshi, S. O., \& Razak, S. H. S. A. (2009). Takaful: Concept, history, development, and future challenges of its industry. Islam and Civilisational Renewal (ICR), 1(2).

Al-Shāțibī, A. I. (2005). al-Muwāfaqāt fì Ușūl al-Sharīah. Kairo: Musțafā Aḥmad, t. th.

Appleby, L., Shaw, J., Amos, T., McDonnell, R., Harris, C., McCann, K., ... Parsons, R. (1999). Suicide within 12 months of contact with mental health services: national clinical survey. Bmj, 318(7193), 1235-1239.

Aris, N. A., Tapsir, R., \& Talib, M. K. A. (2012). Risk and risk management of takaful industry. Journal of Global Business and Economics, 4(1).

Auda, J., Khan, S., \& Al-Shaikh-Ali, A. S. (2008). Maqāṣid Al-Sharī'ah: A Beginner's Guide. International Institute 
of Islamic Thought.

Azhari, I. (2010). Maqasid Al-Shari'ah. Notes of Facilitator.

Bahari, N., \& Ahmad Hidayat Buang. (2015). The Use of Maqasid Al-Syari 'Ah in Fatwa Muamalat in Malaysia: A Literature Review, "Penggunaan Maqasid Al-Syari 'Ah Dalam Fatwa Muamalat Di Malaysia: Kajian Literatur." Journal of Shariah Law Research.

Bakhtiari, S. (2013). Microinsurance and microtakaful: strategies for poverty reduction towards sustainable development. OIDA International Journal of Sustainable Development, 6(01), 93-100.

Bell, C. N., Walton, Q. L., \& Thomas, C. S. (2019). Race and income moderate the association between depressive symptoms and obesity. Preventive Medicine, 119, 1-6.

Bijal, A. S., Kumar, C. N., Manjunatha, N., Gowda, M., Basavaraju, V., \& Math, S. B. (2019). Health insurance and mental illness. Indian journal of psychiatry, 61 (Suppl 4$)$, S791-S797. https://doi.org/10.4103/psychiatry.IndianJPsychiatry_158_19

Duncan, E., Best, C., \& Hagen, S. (2010). Shared decision-making interventions for people with mental health conditions. Cochrane Database of Systematic Reviews, (1).

Erlbeck, A. (2010). Microtakaful-Insuring the Low-income People in Accordance with the Islamic Law. Doctoral dissertation, Diploma Thesis, University of Cologne.

Fisher, O. C. (2000). Awakening of a Sleeping Giant-Rediscovery of Takaful Worldwide. Directory of Islamic Insurance (Takaful).

Ford, T., Goodman, R., \& Meltzer, H. (2003). The British child and adolescent mental health survey 1999: the prevalence of DSM-IV disorders. Journal of the American Academy of Child \& Adolescent Psychiatry, 42(10), 1203-1211.

Gephart Jr., R. P. (2004). Qualitative research and the Academy of Management Journal. Academy of Management Journal.

Haque, A. (2005). Mental health concepts and program development in Malaysia. Journal of Mental Health, 14(2), 183-195.

Hasan, A. (2011). Fundamentals of Shariah in Islamic finance. Institute of Islamic Banking and Finance Malaysia (IBFIM).

Hasim, H. (2014). Microtakaful as an Islamic Financial Instrument, for poverty alleviation in Iraq. Middle-East Journal of Scientific Research, 21(12), 2315-2325.

Hoepfl, M. C. (1997). Choosing qualitative research: A primer for technology education researchers. Journal of Technology Education, 9(1), Fall.

Htay, S. N. N., Sadzali, N. S., \& Amin, H. (2015). An analysis of the viability of micro health takaful in Malaysia. Qualitative Research in Financial Markets.

Hudson, K. L., Rothenberg, K. H., Andrews, L. B., Kahn, M. J. E., \& Collins, F. S. (1995). Genetic discrimination and health insurance: an urgent need for reform. Science, 391-393.

Hussain, M. M., \& Pasha, A. T. (2011). Conceptual and operational differences between general takaful and conventional insurance. Australian Journal of Business and Management Research, 1(8), 23-28.

Institute for Public Health. (2015). National Health and Morbidity Survey 2015 (NHMS 2015).

Jamaiyah, H. (2000). Community mental health in Malaysia: Marriage of psychiatry and public health. Buletin Kesihatan Masyarakat Isu Khas, 155-166.

Joanna, A., \& Dawn, T. (2019). First Critical Illness (CI) plan in Singapore to tackle the taboo of mental conditions head-on with the launch of AIA Beyond Critical Care. Aia.com.sg. Retrieved 27 Feb. 2019, from https://www.aia.com.sg/en/about-aia/media-centre/press-releases/2019/launch-of-aia-beyond-critical-care.html

Khairil, F. K., Laili, N.H., Sabri, H., Basah, M. Y. A., \& Sharifuddin, N. (2017). Implementing Corporate Waqf from the perspective of the Maqasid Shariah: An Analysis. Perlaksanaan Wakaf Korporat Dari perspektif Maqasid Syariah: Satu Analisis. $5^{\text {th }}$ South East Asia International Philanthropy Conference 2017.

Lim, J., Idris, M. F., \& Carissa, Y. (2010, June). History, progress and future challenge of Islamic insurance (Takaful) in Malaysia. In Proceedings from Oxford business and economics conference program. 
Lim, S. L. (2018). Bridging Barriers: A study on improving access to mental healthcare in Malaysia. Retrieved January 29, 2019, from https://penanginstitute.org/programmes/penang-institute-in-kuala-lumpur/1032-bridging-barriers-a-study-on-im proving-access-to-mental-healthcare-in-malaysia/

Min, J. A., Lee, C. U., \& Lee, C. (2013). Mental health promotion and illness prevention: a challenge for psychiatrists. Psychiatry investigation, 10(4), 307.

Nordin, M. M. (2016). Immunisation from the perspective of Maqasid Shariah. Bangladesh Journal of Medical Science, 15(2), 151-153.

Nordin, N., Mohammad, M., Ahmad, A. A., Haron, M. S., \& Daud, N. (2017). Commodity futures: A maqasid al-shariah based analysis. International Journal of Academic Research in Business and Social Sciences, 7(8), 2222-6990.

O'Neil, A., Itsiopoulos, C., Skouteris, H., Opie, R. S., McPhie, S., Hill, B., \& Jacka, F. N. (2014). Preventing mental health problems in offspring by targeting dietary intake of pregnant women. BMC medicine, 12(1), 208.

Patel, S. (2004). Takaful and poverty alleviation. ICMIF. United Kingdom.

Qoyum, A. (2018). Maqasid Ash-Shari'ah Framework and the Development of Islamic Finance Products: The Case of Indonesia. Tazkia Islamic Finance and Business Review, 12(2).

Radzi, M. A. Z. A., Hashi, A. A., \& Sha'ban, M. (2018). An Overview of the Application of Maqasid Al-Shariah into Cartilage Tissue Engineering. IIUM Medical Journal Malaysia, 17(1).

Rathod, S., Pinninti, N., Irfan, M., Gorczynski, P., Rathod, P., Gega, L., \& Naeem, F. (2017). Mental health service provision in low-and middle-income countries. Health Services Insights, 10.

Sadatmoosavi, Z., Ali, W. Z. K. W., \& Shokouh, M. A. (2015). The Objectives (Maqasid Shari'ah) of Observing Modesty and Women's Modest Dress in the Holy Quran. Online Journal of Research in Islamic Studies, 2(3), 13-24.

Sareen, J., Afifi, T. O., McMillan, K. A., \& Asmundson, G. J. (2011). Relationship between household income and mental disorders: findings from a population-based longitudinal study. Archives of General Psychiatry, 68(4), 419-427.

Sayeed, S. A., \& Prakash, A. (2013). The Islamic prayer (Salah/Namaaz) and yoga togetherness in mental health. Indian Journal of Psychiatry, 55(Suppl 2), S224.

Schauer, C., Everett, A., Del Vecchio, P., \& Anderson, L. (2007). Promoting the value and practice of shared decision-making in mental health care. Psychiatric Rehabilitation Journal, 31(1), 54.

Sekandari, N. (2017). OCD: Obsessive Compulsive Disorder and Scrupulosity in Islam - Mental Health 4 Muslims. Retrieved from http://mentalhealth4muslims.com/ocd-obsessive-compulsive-disorder-and-scrupulosity-in-islam/

Sveen, C. A., \& Walby, F. A. (2008). Suicide survivors' mental health and grief reactions: A systematic review of controlled studies. Suicide and Life-Threatening Behavior, 38(1), 13-29.

The Star Online. (2018). Government to Pilot B40 Health Insurance. Retrieved from https://www.thestar.com.my/news/nation/2018/11/03/govt-to-pilot-b40-health-insurance-plan/

Thoits, P. A. (2011). Mechanisms linking social ties and support to physical and mental health. Journal of Health and Social Behavior, 52(2), 145-161.

Toh, B. (2017). Cover Story: Insuring the B40. Retrieved February 27, 2019, from http://www.theedgemarkets.com/article/cover-story-insuring-b40

Yassin, N., \& Ramly, J. (2011). Takaful: A study guide. IBFIM. 